\title{
INFLUENCE OF FEEDING TIME ON FEED UTILIZATION BY SIAMESE CATFISH, Pangasius hypophthalmus JUVENILE
}

\author{
Nina Meilisza*\#, Yann Moreau**), Ettiene Baras ${ }^{* * *}$, and Rina Hirnawati*) \\ ") Research Institute for Ornamental Fish, Depok \\ **) Institut de Recherche pour le Développement
}

(Received 25 February 2010; Accepted 27 May 2010)

\begin{abstract}
Siamese catfish (Pangasius hypophthalmus) at juvenile stage is used as ornamental fish by fish hobbies because of their beautiful shape and movement. Feeding time is a part of feeding management to get the best and effective strategy on feed input. This study aimed to determine the growth of Siamese catfish juvenile by looking at the influence of feeding time on feed utilization. The average individual weight of juveniles used was $\pm 3.2 \mathrm{~g}$ stocked 15 fish per aquarium equipped with recirculation system. Two level factors in the factorial design consisted of 4 feeding times (at 8:00, at 12:00, at 16:00, and as control $(8: 00,12: 00,16: 00)$ and feeding level $(45 \mathrm{~g}$ feed $\mathrm{kg}^{-1}$ fish, $90 \mathrm{~g}$ feed $\mathrm{kg}^{-1}$ fish). Interaction between feeding time and feeding level resulting eight types of treatments research, namely A (8/45), B (12/45), C (16/45), D (8:12:16/45), E (8:12:16/90), F (8/90), G (12/90), and H (16/90). The results showed that feeding time had significant effect on the specific growth rate, feed conversion, and protein efficiency ratio and were significantly different among the treatments $(P<0.05)$. Besides feeding time control (treatments $D$ and $E)$, treatment $C$ also showed the highest of specific growth rate (2.03\%), protein efficiency ratio (1.46), and the lowest feed conversion ratio (1.85).
\end{abstract}

KEYWORDS: feeding time, growth, juvenile, Pangasius hypophthalmus

\section{INTRODUCTION}

In several fish species, it has been demonstrated that the growth performance is strongly dependent on the time of food distribution (Hogendoorn, 1981; Noeske et al., 1981; Sundararaj et al., 1982; Noeske-Hallin et al., 1985; Carrillo et al., 1986; Boujard \& Leatherland, 1992; Kerdchuen \& Legendre, 1994; Baras et al., 1996). In some circumstances, the difference originated from differential food intake at different times of the day (Sundararaj et al., 1982). In most circumstances, however, it is admitted that for fish fed at satiation, the variable growth of fish fed at different times of the day originates from a combination of variable food intake and variable conversion efficiency (Boujard \& Leatherland, 1992).

Several mechanisms can be accounted for the variations of food conversion efficiency, in particular the variable energy expenditure of fish depending on feeding time (Gélineau et al., 1998; Baras, 2000). Variable energy expenditure can originate from a variable propensity of fish to exercise dominance hierarchies and compete for food depending on time of the day and associated light level (Holm, 1989; Jorgensen \& Jobling, 1993; Baras et al., 1998; Baras, 2000). In other situations, the difference was attributed to hour-dependent susceptibility to stress (Boujard et al., 1993), which is

\# Corresponding author. Research Institute for Ornamental Fish, Jl. Perikanan No.13, Depok 41152 , West Java, Indonesia. Tel.: + 620217520482

E-mail address: sirunina@yahoo.com 
known to impact on assimilation processes. Finally, in other circumstances, the differences between the growth rates of fish fed at different times of the day were attributed to different metabolic pathways, for example, channel catfish stocking less energy into perivisceral (fat) reserves when fed during the early morning than during the late afternoon (NoeskeHallin et al., 1985).

Similarly, it has been found that the capacity for protein synthesis varies with feeding time in the rainbow trout (Gélineau et al., 1998). Most research on the influence of feeding time has concerned to comparison between nighttime and daytime feeding, but substantial differences have been observed for meals distributed during the same phase of the day, at a few hours of interval (e.g. Boujard et al., 1993).

From a practical perspective, when experimental data indicate variable growth with different feeding schedules involving different meals shared at different times of the day (as was the case with patin Siamese, our results), it matters discriminating between differential food intake and differential food conversion efficiency. The practical consequences for fish-culturists are substantially different.

One way of solving this issue is carrying out two parallel series of experiment. In the design experiment, the first series (low feeding rate), fish receive meals that are below their maximum food intake. In these circumstances, all food distributed is consumed, and differences in growth, if any, reflect differences in food conversion efficiency. In the second series (high feeding rate), meal size exceeds the maximum food intake of fish. If differences are observed, they can reflect differences between either food intakes or conversion efficiencies, or a combination of both. However, if the results of the second series are compared with those of the first one, it is possible to deduce whether feeding time also impacts on food intake. This is precisely the type of experiment that we wish to implement with young Siamese catfish, Pangasius hypophthalmus. The aim of this experiment will be feed utilization according to feeding time by Siamese catfish, P. hypophthalmus, juvenile.

\section{MATERIALS AND METHODS}

Based on weight gain, Feed Conversion Ratio (FCR) and Protein Efficiency Ratio (PER),
Moreau et al. (2008) estimated the dietary protein requirement for $P$. hypophthalmus was $24 \mathrm{~g} \mathrm{CP} \mathrm{kg}^{-1}$ fish day-1. Based on the last observation, maximum daily feeding rate was estimated at $140 \mathrm{~g} \mathrm{~kg}^{-1}$ day-1 $^{-1}$ for $2 \mathrm{~g}$ fish, with a maximum of $60 \mathrm{~g} \mathrm{~kg}^{-1}$ per meal (Meilisza et al., 2010, unpublished data).

Three meals a day was also defined as optimal feeding frequency for fish ranging 5 to $15 \mathrm{~g}$ (Meilisza et al., 2009, unpublished data). Utilization of appropriate models was shown worthy for studying nutrient requirement or utilization (Shearer, 2000). Moreover, as number of parameters are reduced with a model, experimental design can be optimized by the use of appropriate statistical tools to improve experimental efficiency with lower runs than full factorial design (Ruohonen \& Kettunen, 2004). For the present study, the growth was assumed first as a polynomial function according to treatment, and a uniform design was defined according to this assumption.

Growth performance and nutrient utilisation was compared between lots of fish receiving food at 8,12 , or 16 hours with four different feeding patterns and two daily feeding rates (45 and $90 \mathrm{~g} \mathrm{~kg}^{-1}$ day $^{-1}$ ). Treatments $\mathrm{D}$ and $\mathrm{E}$ served as controls for each daily feeding rate series (Table 1 ).

Triplicates were used for each treatment. Nutrient utilisation was studied on the basis of proximate analysis of feed and of fish at the beginning and at the end of the experiment. Local fish meal, soybean meal, corn meal, fish oil, corn oil, vitamin, and mineral were used as feed ingredients. CMC, $10 \mathrm{~g} \mathrm{~kg}^{-1}$, was used as the binder.

Each diet was formulated according to target nutrient content and proximate composition of feed ingredients, with Microsoft Excel Solver software (Table 2). Pellets were prepared using a $2 \mathrm{~mm}$ dye meat grinder, and slightly dried at ambient temperature. Pellets were then packed in 500-g "zip locked" plastic bags and stored at $4{ }^{\circ} \mathrm{C}$ before utilisation. Dry matter was determined weekly $\left(120^{\circ} \mathrm{C}, 4\right.$ hours $)$ in an aliquot of each diet. Each treatment was randomly assigned to 24 lots of fish as followed (Table 3).

Fifteen fish were used for each lot with an initial fish body mass between 2 and $5 \mathrm{~g}$ (1.5" to $2 ")$. At D-1 (a day before the beginning), 390 fish were randomly assigned to each of these 
Table 1. Meal size $\left(\mathrm{g} \mathrm{kg}^{-1}\right)$ for different treatments according to feeding time

\begin{tabular}{cccc}
\hline \multirow{2}{*}{ Treat ment } & \multicolumn{3}{c}{ Feeding time } \\
\cline { 2 - 4 } & $\mathbf{8 : 0 0}$ & $\mathbf{1 2 : 0 0}$ & $\mathbf{1 6 : 0 0}$ \\
\hline A & 45 & - & - \\
B & - & 45 & - \\
C & - & - & 45 \\
D & 15 & 15 & 15 \\
E & 30 & 30 & 30 \\
F & 90 & - & - \\
G & - & 90 & - \\
H & - & - & 90 \\
\hline
\end{tabular}

Table 2. Feed formulation ( $\mathrm{g}$ dry matter $\mathrm{kg}^{-1}$ feed)

\begin{tabular}{lc}
\hline Feedst uffs & High-Lysine (50\%) \\
\hline Fish meal & 250 \\
Soybean meal & 251 \\
Corn & 355 \\
Fish oil & 10 \\
Corn oil & 54 \\
Vitamins & 30 \\
Mineral & 10 \\
Binder & 10 \\
\hline
\end{tabular}

Table 3. Random assignment of experimental treatments to 24 tanks

\begin{tabular}{|c|c|c|c|}
\hline Tank & Treat ment & Tank & Treat ment \\
\hline $\mathrm{A} 1$ & B & B5 & G \\
\hline $\mathrm{A} 2$ & B & B6 & $E$ \\
\hline $\mathrm{A} 3$ & $\mathrm{H}$ & B7 & $C$ \\
\hline A4 & $E$ & B8 & $\mathrm{G}$ \\
\hline A5 & $\mathrm{C}$ & $\mathrm{Cl}$ & $E$ \\
\hline A6 & D & $\mathrm{C} 2$ & $D$ \\
\hline A7 & B & $\mathrm{C} 3$ & $\mathrm{H}$ \\
\hline A8 & A & $\mathrm{C} 4$ & $\mathrm{H}$ \\
\hline B 1 & A & $\mathrm{C} 5$ & $\mathrm{~F}$ \\
\hline B2 & A & C6 & $\mathrm{F}$ \\
\hline B3 & $\mathrm{F}$ & $C 7$ & G \\
\hline B4 & $\mathrm{C}$ & $\mathrm{C} 8$ & $\mathrm{D}$ \\
\hline
\end{tabular}

24 lots with a supplementary lot of 30 fishes for characterization of initial condition. At D0 , total fish mass was determined in the 24 experimental lots and control fish. In the supplementary lot, fish was weighed individually, and then froze for proximate analysis. 
Every week, total fish biomass and fish number was recorded in each experimental tank. Fish was not fed on sampling days. Meal size was adjusted every week according to fish biomass in each tank. Meals were weighed individually for each tank, weekly. Fish was fed at 08:00, 12:00, and/or 16:00 according to treatment plan. Feed excess or faeces was removed by siphoning one hour after the last meal of the day for each treatment (meaning: 09:00 for treatment $A \& F, 13: 00$ for $B$ \& $G$, and 17:00 for $C, D, E, \& H)$.

Experiment took place in door with a natural photoperiod. Temperature (mini/maxi) was recorded daily. Water quality (dissolved oxygen, $\mathrm{pH}$, ammonia, and nitrite) was controlled each week. Experiment was completed when mass gain reached as high as $200 \%-300 \%$ of the initial mass for the best condition and/or difference among treatments was significant. Significance test was first performed after the $4^{\text {th }}$ sampling week. At the end of the experiment, fish was weighed individually, pooled per tank and froze for proximate analysis. Survival rate was calculated at the end of the experiment by counting the remaining fish in each tank.

\section{RESULT AND DISCUSSION}

Eight design experiments looking at the interaction between feeding time and feeding rate is shown in the Table 4 . The similar performance of survival rate $(100 \%)$ showed on the table has given information that no significant difference could be observed among treatments. Striped catfish juvenile on treatment $E$ $(8: 12: 16 / 90)$ reared during the experiment has the highest final biomass based on feeding time/feeding rate.

Experiment results showed that interaction between feeding time and feeding rate exhibited significant difference on specific growth rate (SGR), feed conversion (FCR), and protein efficiency ratio (PER) $(P<0.05)$. The data for growth rate is provided in Table 5 , and data for feed conversion and protein efficiency ratio is presented in Table 6 . The highest specific growth rate (SGR) was reached by treatment $\mathrm{E}$ (2.24\%) but no significant difference among treatment G (2.18\%), D (2.08\%), C (2.03\%), H (1.97\%), and B (1.73\%) were observed. Compared to the control in treatments $\mathrm{D}$ and $\mathrm{E}$, treatment $\mathrm{G}$ and $\mathrm{C}$ gave good value on SGR.

Based on the comprehensive data obtained during the experiment, the better values of SGR, FCR, and PER was achieved by treatment $C$ with feeding time at 16 and feeding rate of $45 \mathrm{~g} \mathrm{~kg}^{-1}$ fish day ${ }^{-1}$ where the value generated SGR (2.03\%), FCR (1.85\%), and PER (1.46\%). The values of these parameters are not significantly different from that of the control (treatment $\mathrm{D}$ ) which is feeding time at $8,12,16$, and the feeding rate of $45 \mathrm{~g} \mathrm{~kg}^{-1}$ fish day ${ }^{-1}$. This shows that the response of feed on the juvenile of Siamese's catfish is extremely good on feeding time at 16 in the evening than in the afternoon or early morning as indicated by the values of SGR, FCR, and PER are equal to three times a day on feeding time at 8, 12, 16 (control treatment).

The supporting data on the measurement of some physical and chemical parameters of water during the experiment were as follows:

Table 4. Initial biomass, final biomass, and survival rate during the experiment

\begin{tabular}{cccccc}
\hline $\begin{array}{c}\text { Feeding time/feeding } \\
\text { rate } \\
(\mathbf{g} / \mathbf{k g} \text { fish/day) }\end{array}$ & $\begin{array}{c}\text { Initial } \\
\text { biomass } \\
\mathbf{( g )}\end{array}$ & $\begin{array}{c}\text { Final } \\
\text { biomass } \\
\mathbf{( g )}\end{array}$ & $\begin{array}{c}\text { Number of } \\
\text { fish } \\
\text { (ind.) }\end{array}$ & $\begin{array}{c}\text { Survival } \\
\text { rate } \\
\text { (\%) }\end{array}$ \\
\hline $\mathrm{A}$ & $8 / 45$ & 45.78 & 59.73 & 15 & 100 \\
$\mathrm{~B}$ & $12 / 45$ & 47.19 & 68.03 & 15 & 100 \\
$\mathrm{C}$ & $16 / 45$ & 46.60 & 71.57 & 15 & 100 \\
$\mathrm{D}$ & $8 ; 12 ; 16 / 45$ & 47.28 & 73.34 & 15 & 100 \\
$\mathrm{E}$ & $8 ; 12 ; 16 / 90$ & 47.81 & 76.65 & 15 & 100 \\
$\mathrm{~F}$ & $8 / 90$ & 47.30 & 60.64 & 15 & 100 \\
$\mathrm{G}$ & $12 / 90$ & 46.84 & 74.42 & 15 & 100 \\
$\mathrm{H}$ & $16 / 90$ & 47.60 & 72.09 & 15 & 100 \\
\hline
\end{tabular}


temperature from $28^{\circ} \mathrm{C}$ to $30^{\circ} \mathrm{C}$; $\mathrm{pH} 6.8$ to 7.3 , DO 6.15 to 6.68 ; ammonia from 0.03 to 0.57 $\mathrm{mg} / \mathrm{L}$; nitrite from 0.030 to $0.181 \mathrm{mg} / \mathrm{L}$; and conductivity from 256 to $300 \mu \mathrm{S}$. The range of physical and chemical data of water still exists within limits but is still considered optimal to support the survival and growth of fishes. This is reflected in the value of an excellent survival rate which is equal to $100 \%$ and relatively good growth in each treatment (Table 4).

From the observation, it was found that the feeding response of fish in the morning (at 8) was very low and this could be seen from the average weight of fish measured in treatments $A$ and $F$ each week during the experiment which were lower than the other feeding time treatments (Figure 1).

Morning is the time where suspected digestive process has not been activated after a break during the night phase. Besides, fish feeding behavior also affect the response of fish to eat, where it is estimated that there are many factors involved in these processes such as the environment and involvement of some photoreceptor organs (e.g. other parts of the brain, the skin, the eyes) and other organs acting as oscillator (Boujard \& Leatherland, 1992). Ammonia excretion increased immediately after feeding the fish at midnight, and 2 hours after feeding at dawn. Ammonia excretion and energy supply from protein catabolism were higher in fish fed at midnight than in those fed at dawn, while total energy expenditure was the same in both groups.
Table 5 shows the weight gain and specific growth rate of different treatments of feeding time/feeding rate. In addition to the control (treatment $D$ and $E$ ), treatment $C$ and $G$ gain the highest value of weight gain and specific growth rate among other treatments. When compared between treatments, C and G are not significantly different its mean that treatment $C$ is better and more efficiently viewed from a given of feeding rate which is treatment $C$ has lower feeding rate than $\mathrm{G}$. Although treatment $C$ was given feed only once in a day, its growth performance was not significantly different from the control treatment. This suggests that feeding in the evening is effective for seed of Siamese catfish.

Similar to its performance in Table 5 , treatment $\mathrm{C}$ shows the best result in feed conversion as shown in Table 6 where it has the lowest value of 1.85 but not significantly different from the control (treatment D). The highest protein efficiency ratio was also achieved by treatment C (1.46) but again not significantly different from the control (treatment $D$ ). This further indicates that feeding in evening is better than in the afternoon or morning.

The parameters of the experiment showed that feeding in the morning increases the value of feed conversion with the result that feeding efficiency was lower which can cause increased of feed costs. The fed in the morning should not be given more in the fed on a day which viewed that occur of decreasing of feeding efficiency on this time.

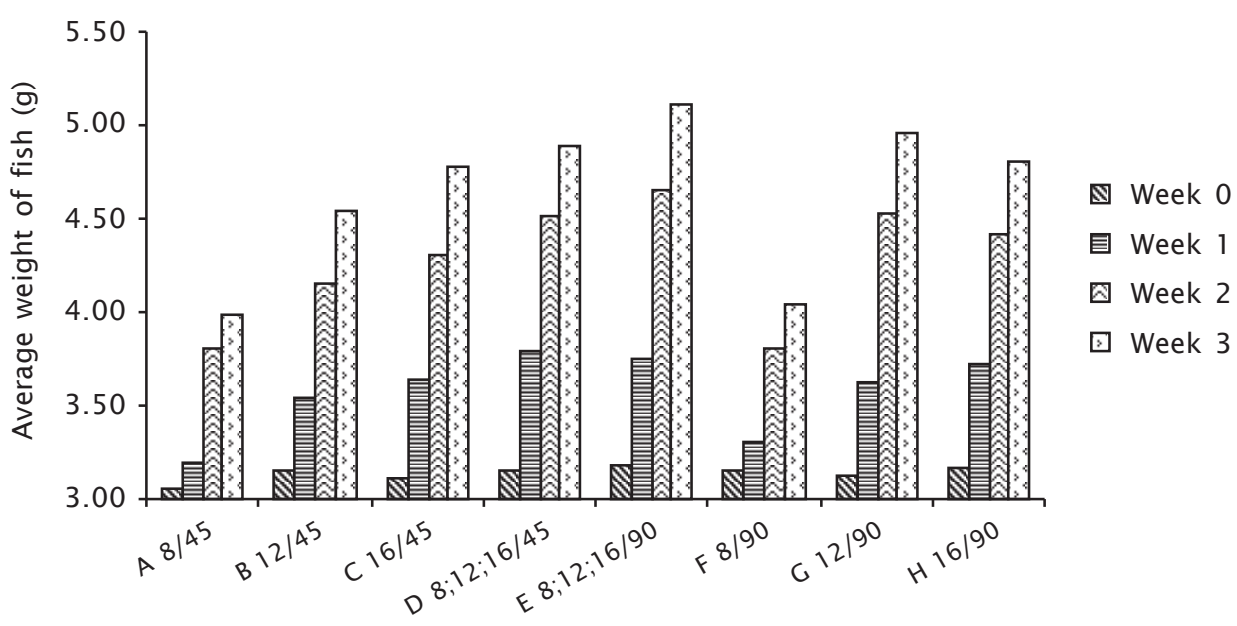

Feeding time and feeding rate treatments

Figure 1. Average weight of fish base on feeding time/feeding rate treatments 
Table 5. Weight gain (g) and specific growth rate (\%/day) based on feeding time/feeding rate treatments

\begin{tabular}{cccccc}
\hline $\begin{array}{c}\text { Feeding time/feeding } \\
\text { rate } \\
\text { (g/kg fish/day) }\end{array}$ & $\begin{array}{c}\text { Initial } \\
\text { weight } \\
\text { (g/ind.) }\end{array}$ & $\begin{array}{c}\text { Final } \\
\text { weight } \\
\text { (g/ind.) }\end{array}$ & $\begin{array}{c}\text { Weight } \\
\text { gain } \\
\text { (g) }\end{array}$ & $\begin{array}{c}\text { Spesific growth } \\
\text { rate } \\
\text { (\%/day) }\end{array}$ \\
\hline $\mathrm{A}$ & $8 / 45$ & 3.05 & 3.98 & 0.93 & $1.26^{\mathrm{bc}}$ \\
$\mathrm{B}$ & $12 / 45$ & 3.15 & 4.54 & 1.39 & $1.73^{\mathrm{abc}}$ \\
$\mathrm{C}$ & $16 / 45$ & 3.11 & 4.77 & 1.66 & $2.03^{\mathrm{abc}}$ \\
$\mathrm{D}$ & $8 ; 12 ; 16 / 45$ & 3.15 & 4.89 & 1.74 & $2.08^{\mathrm{ab}}$ \\
$\mathrm{E}$ & $8 ; 12 ; 16 / 90$ & 3.19 & 5.11 & 1.92 & $2.24^{\mathrm{a}}$ \\
$\mathrm{F}$ & $8 / 90$ & 3.15 & 4.04 & 0.89 & $1.18^{\mathrm{c}}$ \\
$\mathrm{G}$ & $12 / 90$ & 3.12 & 4.96 & 1.84 & $2.18^{\mathrm{a}}$ \\
$\mathrm{H}$ & $16 / 90$ & 3.17 & 4.81 & 1.63 & $1.97^{\mathrm{abc}}$ \\
\hline
\end{tabular}

Note: The same letter following numbers on the same row means not significantly different

Table 6. Feed conversion and protein efficiency ratio according to the feeding time/ feeding rate treatments

\begin{tabular}{cccccc}
\hline $\begin{array}{c}\text { Feeding time/feeding } \\
\text { rate } \\
(\mathbf{g} / \mathbf{k g} \text { fish/day) }\end{array}$ & $\begin{array}{c}\text { Total } \\
\text { feed } \\
\mathbf{( g )}\end{array}$ & $\begin{array}{c}\text { Feed/fish } \\
\mathbf{( g )}\end{array}$ & $\begin{array}{c}\text { Feed } \\
\text { conversion }\end{array}$ & $\begin{array}{c}\text { Protein } \\
\text { efficiency } \\
\text { ratio }\end{array}$ \\
\hline $\mathrm{A}$ & $8 / 45$ & 40.72 & 2.71 & $3.04^{\mathrm{bc}}$ & $0.90^{\mathrm{bc}}$ \\
$\mathrm{B}$ & $12 / 45$ & 43.88 & 2.93 & $2.15^{\mathrm{bc}}$ & $1.25^{\mathrm{ab}}$ \\
$\mathrm{C}$ & $16 / 45$ & 44.78 & 2.99 & $1.85^{\mathrm{c}}$ & $1.46^{\mathrm{a}}$ \\
$\mathrm{D}$ & $8 ; 12 ; 16 / 45$ & 46.39 & 3.09 & $1.82^{\mathrm{c}}$ & $1.48^{\mathrm{a}}$ \\
$\mathrm{E}$ & $8 ; 12 ; 16 / 90$ & 93.89 & 6.26 & $3.29^{\mathrm{b}}$ & $0.81^{\mathrm{bc}}$ \\
$\mathrm{F}$ & $8 / 90$ & 74.50 & 4.97 & $5.60^{\mathrm{a}}$ & $0.47^{\mathrm{c}}$ \\
$\mathrm{G}$ & $12 / 90$ & 87.09 & 5.81 & $3.29^{\mathrm{b}}$ & $0.82^{\mathrm{bc}}$ \\
$\mathrm{H}$ & $16 / 90$ & 83.15 & 5.54 & $3.41^{\mathrm{b}}$ & $0.78^{\mathrm{bc}}$ \\
\hline
\end{tabular}

Note: The same letter following numbers on the same row means not significantly different

The phenomenon of this result given assumption that the fed in the morning will make the low of growth caused by the decreasing of feeding appetite and consumption. Physiological aspects that potentially affect the feeding time (Noeske-Hallin et al., 1985) have been able to be proven in this experiment.

\section{CONCLUSION}

The different treatments of feeding time positively affect growth performance, feed conversion, and protein efficiency ratio of tested fish. Feeding time at 16:00 with feeding rate of $45 \mathrm{~g} \mathrm{~kg}^{-1}$ leads to the highest performance on growth, feed conversion, and protein efficiency ratio of fish (treatment $\mathrm{C}$ ).

\section{REFERENCES}

Boujard, T. \& Leatherland, J.F. 1992. Circadian rhythms and feeding times in fishes. Env. Biol. Fishes, 35: 109-131.

Boujard, T., Brett, S., Lin, L., \& Leatherland, J.F. 1993. Effect of restricted access to demand feeder on diurnal pattern of liver composition, plasma metabolites and hormone levels in Oncorhynchus mykiss. Fish Physiol. and Biochem., 11 (1-6): 337-344.

Baras, E., Mélard, C., Grignard, J.C., \& Thoreau, X. 1996. Comparison of food conversion by the Pirapatinga Piaractus brachypomus under different times of feeding. Prog. Fish Cult., 58: 59-61. 
Baras, E., Tissier, F., Westerloppe, L., Mélard, C., \& Philippart, J.-C. 1998. Feeding in darkness alleviates density-dependent growth of juvenile vundu catfish Heterobranchus longifilis (Clariidae). Aquat. Living Res., 11 : 335-340.

Baras, E. 2000. Day-night alternation prevails over food availability in synchronising the activity of Piaractus brachypomus (Characidae). Aquat. Living Res., 13: 115-120.

Carrillo, M.A., Perez, J., \& Zanuy, S. 1986. Efecto de la hora de injesta de la naturaleza de la dieta sobre el crecimiento de la lubina (Dicentrarchus labrax L.). Investigacion Pesquades., 50: 83-95.

Cowey, C.B. \& Luquet, P. 1983. Physiological basis of protein requirements of fishes. Critical analysis of allowance. INRA Éditions, Paris, p. 365-384.

Garling Jr., D.L. \& Wilson, R.P. 1976. Optimum dietary protein to energy ratio for channel catfish fingerling, Ictalurus punctatus. J. of Nutrition, 106: 1368-1375.

Gatlin, D.M., III, Poe, W.E. \& Wilson, R.P. 1986. Protein and energy requirements of fingerling channel catfish for maintenance and maximum growth. J. of Nutrition, 116, 2121 2131.

Gélineau A., Médale, F., \& Boujard, T. 1998. Effect of feeding time on postprandial excretion and energy expenditure in rainbow trout. J. Fish Biol., 52: 655-664.

Hogendoorn, H. 1981. Controlled propagation of the African catfish, Clarias lazera (C\&V). IV. Effect of feeding regime in fingerling culture. Aquaculture, 24: 123-131.

Holm, J.C. 1989. Mono and duoculture of juvenile Atlantic salmon (Salmo salar) and Arctic charr (Salvelinus alpinus) - Can. J. Fish. Aquat. Sci., 46(4): 697-704.

Hung, L.T. 1999. Contribution à l'étude de l'élevage larvaire et de la nutrition des juvéniles de deux poissons-chats du Mékong, Pangasius bocourti (Sauvage, 1880 ) et Pangasius hypophthalmus (Sauvage, 1878), Vol. PhD, Institut National Agronomique Paris-Grignon, $161 \mathrm{pp}$.

Hung, L.T., Lazard, J., Mariojouls, C., \& Moreau, Y. 2003. Comparison of starch utilization in fingerlings of two Asian catfishes from the Mekong river (Pangasius bocourti Sauvage, 1880, Pangasius hypophthalmus Sauvage, 1878). Aquaculture Nutrition, 9: 215-222.
Hung, L.T., Suhenda, N., Slembrouck, J., Lazard, J., \& Moreau, Y. 2004. Comparison of dietary protein and energy utilization in three Asian catfishes (Pangasius bocourti, $P$. hypophthalmus, and P. djambal). Aquaculture Nutrition, 10: 317-326.

Jorgensen, E.H. \& Jobling, M. 1993. Feeding in darkness eliminates density-dependent growth suppression in Arctic charr. Aquacult. Intern., 1: 90-93.

Kerdchuen, N. \& Legendre, M. 1994. Influence de la fréquence et de la période de nourrissage sur la croissance et l'efficacité alimentaire d'un silure africain, Heterobranchus longifilis (Teleostei, Clariidae). Aquat. Living Res., 4: 241-248.

Meilisza, N. 2010. Modifikasi frekuensi pemberian pakan berdasarkan proporsi harian terhadap pertumbuhan benih ikan patin siam (P. hypophthalmus). Prosiding Seminar Nasional Tahunan VII Hasil Penelitian Kelautan dan Perikanan. Universitas Gadjah Mada, Yogyakarta (Unpublish).

Moreau, Y., Meilisza, N., Subamia, I W., Hirnawati, R., \& Ediwarman. 2008. Influence of protein to energy ratio on determination optimal feeding rate for stripped catfish, Pangasiodon hypophthalmus. Submitted to Asian Fisheries Science Journal.

Noeske, T.A., Erickson, D., \& Spieler, R.E. 1981. The time of the day goldfish receive a single daily meal affects growth. J. World Maricult. Soc., 12: 73-77.

Noeske-Hallin, T.A., Spieler, R.E., Parker, N.C., \& Suttle, M.A. 1985. Feeding time differentially affects fattening and growth of channel catfish. J. Nutr., 115: 1228-1232.

Ruohonen, K. \& Kettunen, J. 2004. Effective experimental designs for optimizing fish feeds. Aquaculture Nutrition, 10: 145-151.

Shearer, K.D. 2000. Experimental design, statistical analysis and modelling of dietary nutrient requirement studies for fish: a critical review. Aquaculture Nutrition, 6: 91102.

Spieler, R.E. \& Clougherty, J.J. 1989. Free-running locomotor rhythms of feeding-entrained goldfish. Zool. Sci., 6(4): 813-816.

Sundararaj, B.I., Nath, P., \& Halberg, F. 1982. Circadian meal timing in relation to lighting schedule optimizes catfish body weight gain. J. Nutr., 112: 1085-1097. 